\title{
Bankruptcy Prediction Model for Listed Companies in Romania
}

\author{
Vintilă Georgeta and Toroapă Maria Georgia
}

Academy of Economic Studies, Bucharest, Romania

\begin{abstract}
Z-score model is one of the most frequently used model for early financial failure warning and considers various financial ratios selected as prediction variables.The purpose of this paper is to use multivariant discriminant analysis (MDA) to substantiate a score function effective in bankruptcy risk prediction of enterprises on Romanian economy example. In order to discriminate between bankrupt and non-bankrupt in the scoring model we used relevant financial ratios related to activity, liquidity, leverage and profitability. The weighting coefficients established between independent variables and the objective function-score, are determined by using statistical tools. In this context, the article aims to build a scoring function in order to identify bankrupt companies, using a sample of companies listed on Bucharest Stock Exchange. The results in this article can be used to appraise the effectiveness of applying MDA financial failure models for Romanian companies, to make an idea about curent and future financial situation, and take, if necessary, corrective measures.
\end{abstract}

Key words: discriminant analysis, bankruptcy, prediction, financial ratios, score.

JEL Classification: C38, G33, G17, G32, C52.

\section{Introduction}

Financial failure prediction is a critical factor in developing strong-built capital markets in most of the capitalistic countries and numerous studies in the field of economic and financial analysis focus on bankruptcy early warning. Creditors and investors are greatly concerned with the possibility of company's bankruptcy. While the lenders are interested in the credit worthiness of the firm, shareholders are more heavily involved with profits and dividends prospects. Financial statements are a valuable source of information for the decision makers as a benchmark for future targets and projections.

Most of corporate management studies include a section about why companies fall into bankruptcy. Slatter (1984), for example, identified eleven factors as the principal causes of corporate decline. The first one is the poor management factor which may emerge as sheer incompetence or lack of interest in the top management. Apart from poor management, another major factor for corporate decline is the inadequate financial control which occurs in the absence of or inadequacy of cash-flow forecasts, costing systems and budgetary control. Other financial causes of decline are high gearing, conservative financial policies, the use of inappropriate financing sources, high cost structure, adverse movements in commodity prices and overtrading. In addition, competition between firms, irresponsiveness to market demand changes, lack of marketing effort, launching big projects without prior

Copyright (C) 2012 Vintilă Georgeta and Toroapă Maria Georgia. This is an open access article distributed under the Creative Commons Attribution License unported 3.0, which permits unrestricted use, distribution, and reproduction in any medium, provided that original work is properly cited. Contact author: Vintilă Georgeta E-mail: vintilageorgeta@yahoo.fr 
planning and not-properly scrutinized acquisitions might potentially give rise to corporate failures as well.

Included by theorists in "professional applications of financial analysis" or by practitioners in "other methods of financial analysis", discriminate analysis can be also seen as a method belonging to the stage of maturity of financial analysis. The scoring is a method that involves internal and external diagnostic and requires risk interpretation for the investor, company's creditor, but also for the enterprise as a system in further activities. It is based on a value judgment development that combines a relevant group of financial ratios (or variables).

The purpose of this article is to review and examine the main early warning bankruptcy approaches, particularly the ' $\mathrm{Z}$ models' that are utilized as valuable symptoms of potential failure. The article consists of five parts. The Introduction is followed by sections covering Literature Review, Methodology, Results and Conclusions.

\section{Literature Review}

Science-based models for bankruptcy prediction have been developed for the first time in U.S. in the ' 60 s by W.H. Beaver and E.I. Altman. Beaver found that several indicators could successfully distinguish a sample of bankrupt companies to another one without financial difficulties, obtaining conclusive results for a period of up to five years before the onset of bankruptcy. Beaver examined financial ratios independently, without taking into account the existing links between them, resulting in a univariate or one-dimensional analysis. He has, however, the ground work for multivariate analysis, which was developed by Altman and by other economists, whose outcome is to develop a scoring model based on a combination of rates that distinguish the most risky businesses compared to the healthy ones.
E.I. Altman developed in 1968, a multivariate analysis of bankruptcy, combining five financial ratios in a single function, popularized as the score or Z-score model. Subsequently, this model was improved and published under the name "Zeta Analysis", standing at the base of other bankruptcy prediction models.

The Z-score model suggested by Altman is based on discriminant analysis, which is used to develop models of classification and prediction of observations belonging to certain groups determined a priori. To this end, the discriminant analysis builds a classifier based on a set of observations and indicators characteristic for these observations. In the case of Altman model the set of observations is represented by a number of companies classified by the author in solvent and insolvent, and the considered indicators are certain financial ratios based upon the financial situation of companies is analyzed.

Ohlson (1980) uses a logit model, with less restrictive assumptions than those taken by the MDA approach. Zmijewski (1984) adopts a probit approach that is also based on accounting data but uses a different set of independent variables. All of these approaches predict future bankruptcy based on accounting ratios extracted from publicly available financial statements.

Shumway (2001) proposed a discrete-time hazard model to predict a company's bankruptcy using both accounting and market variables. The main difference between this model and the static logit model is that the hazard model can be estimated within the logit framework while using the entire life span of information (all companyyears) for each firm. By contrast, the static logit model incorporates only one firm-year for each observation (i.e., each observation consists of a single set of variables observed at a single point in time). 
Another reference of the bankruptcy prediction literature focuses on marketbased information. Among others, Hillegeist (2004) has developed a BSM-Prob bankruptcy prediction model that is based on the Black-Scholes-Merton option pricing model. Their results indicate that the BSMProb model outperforms the models of Altman (1968) and Ohlson (1980) in a series of tests.

Recent papers take into consideration also various firm-characteristics that may be useful additional predictors of future bankruptcy are taken. For example Denis et al. (1997) measure corporate diversification by the number of business segments. Beaver et al. (2005) propose that, other things equal, large firms have a smaller probability of bankruptcy and that a part of this explanation is related to corporate diversification. That is, corporate diversification and firm-size are two firmcharacteristics that may help to predict future bankruptcy. Verwijmeren et al. (2010) remark that companies with strong interest in employee well-being reduce the chance of bankruptcy.

Hillegeist et al. (2004) compare the performance of their BSM-Prob model against the Altman and Ohlson models in a series of in-sample and out-of-sample tests, concluding that the BSM model outperforms the accounting-based models. Similarly, Chava and Jarrow (2004) examine the relative performance of Shumway's hazard model against the Altman and Zmijewski models, concluding that the hazard model outperforms static logit models.

Romania has expressed also an interest in obtaining a synthetic tool to forecast the risk of bankruptcy in banks and businesses. In this regard, should be mentioned: the B Score Function (1998), developed by D. Băileșteanu, Model I (1998) built by Ivoniciu (similar to B Score Function), Model A (2002) Ion Anghel's outcome on the Romanian economy.
Bankruptcy prediction models using MDA in Romanian economy context are also highlighted in latest studies (Vintilă and Toroapă, 2011) in order to achieve discrimination between bankrupt and nonbankrupt in the scoring model based on relevant financial ratios related to activity (stock rotation, receivable collection, debt payment,assets rotation), liquidity(current liquidity quick liquidity), leverage (equity debt, cash-flow to debt, debt to total assets) and profitability (return on sales, return on assets, return on equity, return on revenue). Another recent study for bankruptcy risk estimation (Armeanu, Vintilă et al., 2012) achieves eligible results with the built score model based on financial ratios for the Romanian economy's framework.

Scoring models framed so far have the disadvantage that can be applied only in economies where the statistical study was conducted (or branch or sector analyzed), their use cannot be generalized territorially. Therewith, periods marked by economic instability change the correlations captured by the score function developed, which limits the temporal use of these models, requiring a re-enactment at regular intervals.

\section{Research Methodology}

The purpose of this paper is to use discriminant analysis to substantiate a score function effective in bankruptcy risk prediction of enterprises on Romanian economy example. For achieving discrimination between bankrupt and nonbankrupt in the scoring model we used relevant financial ratios related to activity (stock rotation, receivable collection, debt payment,assets rotation), liquidity(current liquidity quick liquidity), leverage (equity debt, cash-flow to debt, debt to total assets) and profitability (return on sales, return on assets, return on equity, return on revenue). 
The research was conducted on a sample of 50 companies listed on the Bucharest Stock Exchange, out of which 27 were used to build the score function and 23 for a posterior analysis in determining the success rate of it. This analysis is based on financial information extracted from annual reports of companies (balance sheet, profit and loss, the Annexes to the financial statements) for the year 2008.

The sample considered in building the score function includes 27 Romanian companies both from public and private out of which 13 companies without financial problems and 14 companies are bankrupt or in difficulty (it was opened the insolvency proceeding) according to information posted on the Ministry of Finance website.

Detailed analysis of the sample allowed appraisal of the obvious differences between the two groups of enterprises. For this analysis there have been used the average and median of the financial ratios, most relevant being the median rates which eliminate unusual values encountered in some cases (see Table 1).

Table 1: Average (AVG) and Median (MDN) of the Financial Ratios for the Two Groups NonBankrupt/Bankrupt

\begin{tabular}{|l|c|c|c|c|}
\hline \multirow{2}{*}{ Financial Ratios } & \multicolumn{2}{|c|}{ N-B } & \multicolumn{2}{c|}{ B } \\
\cline { 2 - 5 } & AVG & MDN & AVG & 0.67 \\
\hline Current liquidity & 4.49 & 1.82 & 0.46 & 0.36 \\
\hline Quick liquidity & 4.01 & 1.35 & -0.19 & 0.03 \\
\hline Equity debt & 0.16 & 0.01 & -0.01 & 0.00 \\
\hline Cash-flow to debt & 1.23 & 0.00 & $91 \%$ & $83 \%$ \\
\hline Debt to asset & $29 \%$ & $30 \%$ & 73 & 71 \\
\hline Stock rotation (days) & 39 & 45 & 124 & 89 \\
\hline Receivable collection (days) & 137 & 107 & 709 & 466 \\
\hline Total debt payment (days) & 161 & 127 & 127 & 115 \\
\hline Supplier payment (days) & 44 & 28 & 0.67 & 0.61 \\
\hline Asset rotation & 0.71 & 0.63 & $-30 \%$ & $-18 \%$ \\
\hline Return on sales & $16 \%$ & $9 \%$ & $-132 \%$ & $-32 \%$ \\
\hline Return on equity & $9 \%$ & $8 \%$ & $-82 \%$ & $-11 \%$ \\
\hline Return on asset & $10 \%$ & $10 \%$ & $-35 \%$ & $-21 \%$ \\
\hline Return on revenue & $14 \%$ & $6 \%$ & & \\
\hline
\end{tabular}

(Own calculations)

Following the selection step for the discrimination of the two categories we kept the following five financial variables: current liquidity, return on asset, return on revenues, debt to asset, total debt payment.

Current Liquidity $=$ Current Assets $/$ Current Liabilities
Return on Asset = Gross Profit / (Equity + Long Term Liabilities)

Return on Revenues $=$ Net Profit $/$ Total Revenues

Debt to Asset $=$ Total Debt $/$ Total Assets 
5 Journal of Eastern Europe Research in Business \& Economics

Total Debt Payment (days) $=$ (Total Debt $/$ Turnover) X 360 .

\section{Research Results}

The model has the following function:

Z=Function(Rentability

of Revenues,Rentability of Assets, Debt to Asset, Current Liquidity, Total Debt Payment).

The model which describes the relationship between the rentability of incomes, rentability of assets, leverage global rate, liquidity ratio and payment obligations is a strong and linear relationship. The model is valid.Three parameters are nor statistical significant, but the model could be revised. The Durbin-Watson test is 1.74 , which means that there is indecision, it is recommending to accept the positive autocorrelation of residuals. The value for coefficient of determination is $68 \%$, which means that the model is explained in $68 \%$ of the exogenous variables. For checking the homoskedasticity hypothesis for this model will be using White test. White-test involves the following steps:

- Initial model parameter estimation and calculation of estimated residual variable;

- Build an auxiliary regression based on presumption that it is a relationship between the square error values, exogenous variables included in the initial model and the square of its values. In the model presents. heteroskedasticity. In our vision, the model can be applied for prognosis, because it will be revised and it can be added more data and more variables for increasing the validity of this model.

In our opinion if the value of $\mathrm{Z}$ is included in the interval $(-1 ;+1)$, the company will be in bankruptcy.

Table 2: Descriptive Statistics for Studied Indicators

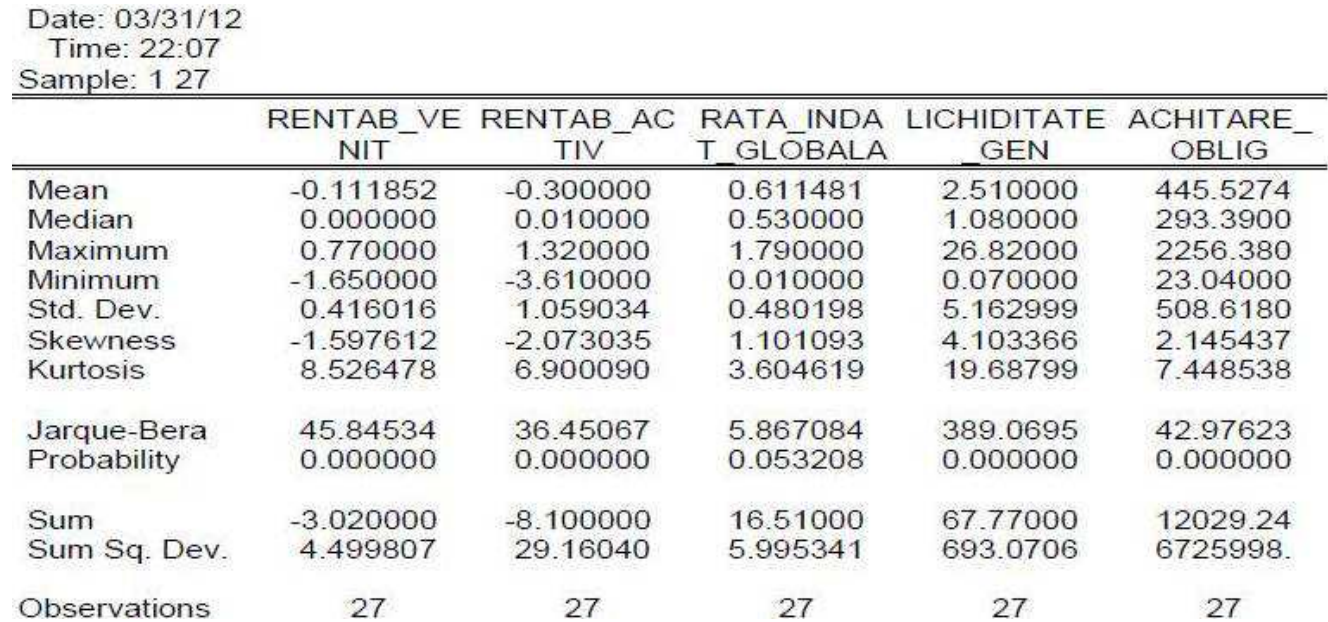


Journal of Eastern Europe Research in Business \& Economics 6

Table 3: The White Test

White Heteroskedasticity Test:

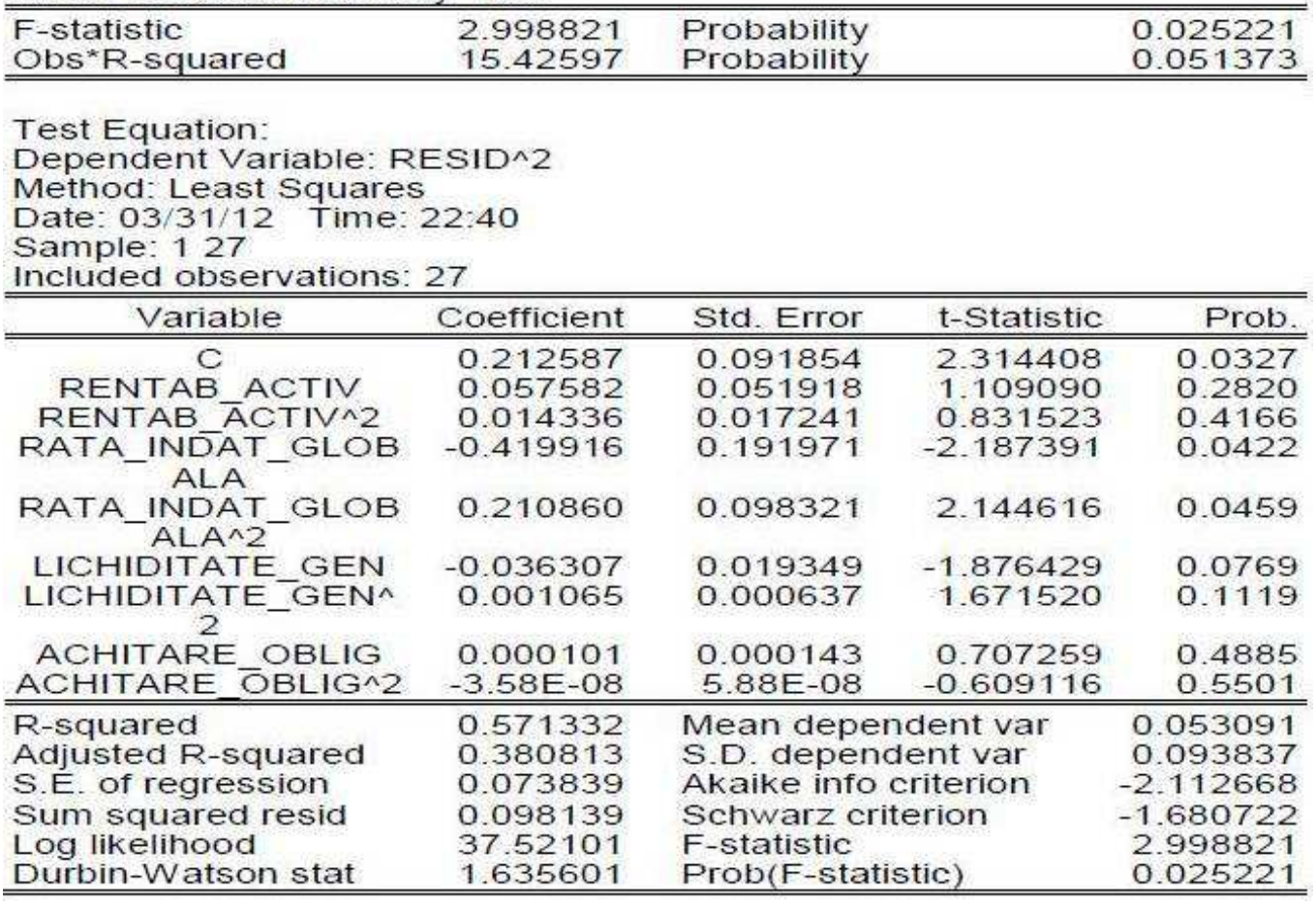


7 Journal of Eastern Europe Research in Business \& Economics

Table 4: Excel Output

\begin{tabular}{|c|c|c|c|c|c|c|}
\hline \multicolumn{7}{|l|}{ SUMMARY OUTPUT } \\
\hline \multicolumn{7}{|c|}{ Regression statistics } \\
\hline Multiple $\mathrm{R}$ & 0,825185327 & & & & & \\
\hline R square & 0,680930824 & & & & & \\
\hline Adjusted R Square & 0.622918246 & & & & & \\
\hline Standard Error & 0,255391118 & & & & & \\
\hline Observations & 27 & & & & & \\
\hline \multirow{2}{*}{\multicolumn{7}{|c|}{ ANOVA }} \\
\hline & & & & & & \\
\hline Regression & $d f$ & $\frac{55}{3.062332937}$ & MS & $\frac{F}{13,73764}$ & significance F & \\
\hline Residual & 22 & $\begin{array}{l}3,062332912 \\
1,434941709\end{array}$ & 0,065225 & 11,73764 & 0,00003 & \\
\hline \multirow[t]{3}{*}{ Total } & 26 & 4.497274621 & & & & \\
\hline & & & & & & \\
\hline & Coefficients & Standard Error & tstat & P-value & Lower 9596 & Upper $95 \%$ \\
\hline intercept & 0,30602619 & 0,098942941 & 3.092956 & 0.005312 & 0.100831091 & 0,51122129 \\
\hline rentab activ & 0,002711617 & 0,01077444 & 0,251671 & 0,803631 & $-0,019633204$ & 0,025056437 \\
\hline rata indat & $-0,657805297$ & 0,144301684 & $-4,55854$ & 0,000154 & $-0,957068671$ & $-0,358541923$ \\
\hline Iichidit gen & $-9,5811 A$ E-OS & 0,0001285 & $-0,74562$ & 0,463792 & $-0,000362303$ & 0,00017068 \\
\hline achitare oblig & 0.064561867 & 0,049234298 & $-1,31132$ & 0,203272 & -0.166667551 & 0,037543816 \\
\hline & & & & & & \\
\hline & & & & & & \\
\hline \multicolumn{7}{|l|}{ RESIDUAL OUTPUT } \\
\hline & & & & & & \\
\hline Observation & Dredicted rentab vernit & Residuals & & & & \\
\hline$\frac{1}{2}$ & 0.097033595 & -0.040522613 & & & & \\
\hline $\begin{array}{l}2 \\
3\end{array}$ & $\begin{array}{l}-0,098630611 \\
0,087865636\end{array}$ & $\begin{array}{r}0,18188075 \\
-0,04214053\end{array}$ & & & & \\
\hline$\Delta$ & 0,02281058 & $-0,021514464$ & & & & \\
\hline 5 & 0,034547433 & 0,018172046 & & & & \\
\hline$\sigma$ & $-0,147745713$ & 0.156809276 & & & & \\
\hline 7 & $-0,041632875$ & 0,043881745 & & & & \\
\hline $\mathbf{s}$ & 0,308223418 & $-0,081694452$ & & & & \\
\hline 9 & 0,338920153 & 0,090074192 & & & & \\
\hline 10 & 0,199038046 & $-0,101322896$ & & & & \\
\hline 11 & 0,170775251 & 0,142835866 & & & & \\
\hline 12 & 0,250613351 & $-0,179919663$ & & & & \\
\hline 13 & 0,174695087 & 0,591735291 & & & & \\
\hline 14 & -0.106972356 & 0,114741198 & & & & \\
\hline is & -0.495428103 & 0,178546577 & & & & \\
\hline 16 & $-0,149071422$ & 0,149511057 & & & & \\
\hline 17 & $-0,041582239$ & $-0,342532578$ & & & & \\
\hline 18 & $-0,163961594$ & 0,109907647 & & & & \\
\hline 19 & -0.240173409 & 0,025083282 & & & & \\
\hline 20 & $-0,648136715$ & 0,217518561 & & & & \\
\hline 21 & 0,107479411 & $-0,205163941$ & & & & \\
\hline 22 & $-1,05910604$ & $-0,592251834$ & & & & \\
\hline 23 & $-0,293201156$ & $-0,221056739$ & & & & \\
\hline 24 & $-0,100053176$ & -0.109403501 & & & & \\
\hline 25 & $-0,967464205$ & 0,39674015 & & & & \\
\hline 26 & $-0,199419203$ & 0,087879424 & & & & \\
\hline 27 & $-0,129778422$ & $-0,282122118$ & & & & \\
\hline
\end{tabular}

Table 5: Eviews Output

\begin{tabular}{|c|c|c|c|c|}
\hline \multicolumn{5}{|c|}{ 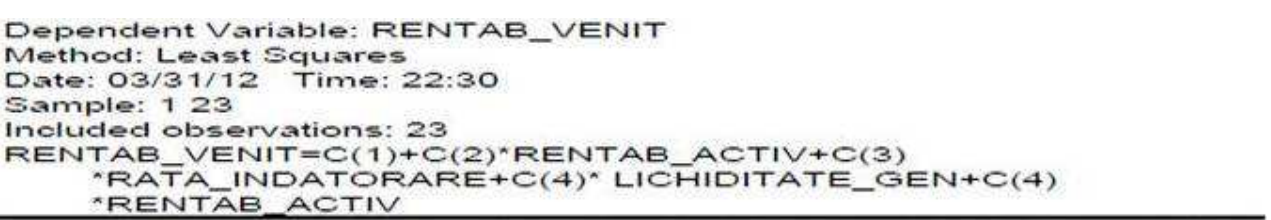 } \\
\hline & Coefficient & Std. Error & t-Statistic & Prob. \\
\hline $\begin{array}{l}\sigma(1) \\
C(2) \\
c(3) \\
C(4)\end{array}$ & $\begin{array}{r}0.128439 \\
0.008012 \\
-0.363087 \\
0.004555 \\
\end{array}$ & $\begin{array}{l}0.142875 \\
0.048703 \\
0.154490 \\
0.044621 \\
\end{array}$ & $\begin{array}{r}0.898962 \\
0.123447 \\
-2.350100 \\
0.102071 \\
\end{array}$ & $\begin{array}{l}0.3799 \\
0.9030 \\
0.0297 \\
0.9198 \\
\end{array}$ \\
\hline $\begin{array}{l}\text { R-squared } \\
\text { Adjusted R-squared } \\
\text { S.E. of regression } \\
\text { Sum squared resid } \\
\text { Log likelihood }\end{array}$ & $\begin{array}{l}0.412584 \\
0.319834 \\
0.182048 \\
0.629889 \\
8.741678\end{array}$ & $\begin{array}{l}\text { Mean depe } \\
\text { S.D. deper } \\
\text { Akaike info } \\
\text { Sohwarz or } \\
\text { Durbin-Wa }\end{array}$ & $\begin{array}{l}\text { dent var } \\
\text { ent var } \\
\text { riterion } \\
\text { rion } \\
\text { on stat }\end{array}$ & $\begin{array}{r}-0.094348 \\
0.220739 \\
-0.412320 \\
-0.214843 \\
2.193105\end{array}$ \\
\hline
\end{tabular}



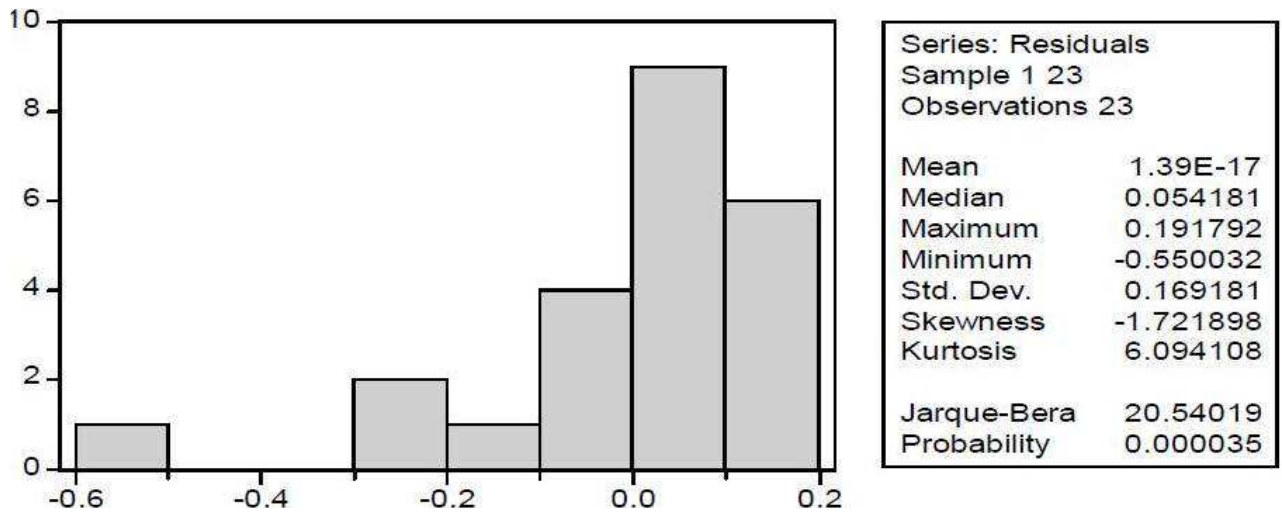

Fig 1. The Jarque-Bera Test

Table 6: The Actual, Fitted Values and Residuals

\begin{tabular}{|c|c|c|c|c|c|}
\hline obs & Actual & Fitted & Residual & Residual & \\
\hline 1 & 0.02000 & -0.05297 & 0.07297 &.$\left.\right|^{*}$. & \\
\hline 2 & 0.01000 & -0.10186 & 0.11186 &.$\left.\right|^{*}$. & 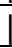 \\
\hline 3 & 0.01000 & -0.02863 & 0.03863 & $.1^{*}$. & \\
\hline 4 & 0.05000 & -0.00805 & 0.05805 & . $1^{*}$. & 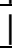 \\
\hline 5 & 0.08000 & -0.04713 & 0.12713 & \begin{tabular}{l|l} 
& $*$ \\
.
\end{tabular} & \\
\hline 6 & 0.19000 & 0.12135 & 0.06865 &.$\left.\right|^{*}$. & 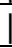 \\
\hline 7 & 0.05000 & 0.02264 & 0.02736 & $.1^{*}$. & \\
\hline 8 & 0.09000 & 0.03037 & 0.05963 & $.1^{*}$. & \\
\hline 9 & 0.01000 & 0.06259 & -0.05259 & $*^{*} \mid$. & \\
\hline 10 & 0.04000 & 0.08430 & -0.04430 & ${ }^{*} \mid$. & \\
\hline 11 & -0.73000 & -0.43876 & -0.29124 & $* .1$. & \\
\hline 12 & -0.14000 & -0.31653 & 0.17653 & . $\left.\right|^{*}$ & \\
\hline 13 & -0.23000 & -0.32106 & 0.09106 & $.1^{*}$. & \\
\hline 14 & 0.00000 & -0.19179 & 0.19179 & \begin{tabular}{l|l}
$*$ & $*$ \\
\end{tabular} & \\
\hline 15 & -0.22000 & -0.14049 & -0.07951 & $.^{*} \mid$. & \\
\hline 16 & -0.19000 & -0.13700 & -0.05300 & ${ }^{*} \mid$. & \\
\hline 17 & -0.66000 & -0.10997 & -0.55003 & .1. & \\
\hline 18 & 0.00000 & -0.16524 & 0.16524 & . $\left.\right|^{*}$ & \\
\hline 19 & -0.04000 & -0.09418 & 0.05418 & . $\left.\right|^{*}$ & \\
\hline 20 & -0.22000 & -0.00047 & -0.21953 & $* .1$. & \\
\hline 21 & 0.00000 & -0.03379 & 0.03379 & . $\left.\right|^{*}$. & \\
\hline 22 & -0.12000 & -0.01556 & -0.10444 & $*^{*} \mid$. & \\
\hline 23 & -0.17000 & -0.28777 & 0.11777 & $.1 *$. & \\
\hline
\end{tabular}

\section{Conclusions}

Corporate financial failure prediction is of critical importance for mangers, stakeholders and other parties related. In the literature, many researchers have focused on the financial ratios of corporations for failure prediction.

Given the current economic situation, trying to build a bankruptcy prediction function score for Romanian companies is a real challenge. 
In our vision, the model can be applied for prognosis, because it will be revised and it can be added more data and more variables for increasing the validity of this model. In our opinion if the value of $\mathrm{Z}$ is included in the interval $(-1 ;+1)$, the company will be in bankruptcy.

Discriminant analysis as relevant method in the arsenal of economic and financial analysis tools will become a necessity in the next period, for understanding and applying the economic reality in predicting specific questions of interest to users of financial and economic information. This may prove effective for: further research bankruptcy prediction in companies with specific application to economic sectors or small and medium enterprises; judging companies operational activity by auditors and accountants; using score functions to provide information to investors concerned about finding the most profitable investments, or solutions for their portfolio in order to earn an optimal overall return-risk per share; using discriminant analysis in the macroeconomics, in areas such as analysis and prediction of success vs. failure of specific economic policies on the development of disadvantaged areas; implementing economic programs for the development of certain industries or sectors.

\section{References}

Altman, E. I. (1968). "Financial Ratios, Discriminant Analysis and the Prediction of Corporate Bankruptcy," Journal of Finance 23, 589-609.

Anghel, I. (2000). 'Bankruptcy Prediction in Romanian Enterprises,' Economic Tribune, Bucharest.

Armeanu, S. D., Vintilă, G., Moscalu, M., Filipescu, M. O. \& Lazar, P. (2012). "Using Quantitative Data Analysis Techniques for Bankruptcy Risk Estimation for Corporations," Theoretical and Applied Economics, Volume XIX (2012), No. 1(566), 97-112.
Băileșteanu, G. (1998). 'Diagnosis, Risk and Business Efficiency,' Mirton Publishing House, Timişoara.

Barbier, A. \& Proutat, J. (1990). Traite Pratique De L'analyse Financiere A L'usage Des Banques, Paris.

Beaver, W. H. (1966). Financial Ratios As Predictors of Failure, Empirical Research in Accounting, Selected Studies,Supplement to Journal of Accounting Research.

Beaver, W. H., McNichols, M. F. \& Rhie, J. W. (2005). "Have Financial Statements Become Less Informative? Evidence from the Ability of Financial Ratios to Predict Bankruptcy," Review of Accounting Studies 10, 93-122.

Chava, S. \& Jarrow, R. A. (2004). "Bankruptcy Prediction with Industry Effects," Review of Finance 8, 537-569.

Cohen, E. \& Sauriel, A. (1990). Analyse Financiere-Outils ET Applications, Economic Publishing House, Paris.

Denis, D. J., Diane, K. D. \& Atulya, S. (1997). "Agency Problems, Equity Ownership, and Corporate Diversification," Journal of Finance 52, 135-160.

Hillegeist, S. A., Keating, E. K., Cram, D. P. \& Lundstedt, K. G. (2004). "Assessing the Probability of Bankruptcy," Review of Accounting Studies 9, 5-34.

Ivoniciu, P. (1998). 'Analysis of Bankruptcy Risk through Score Method,' Finance, Banks, Insurance Magazine, Bucharest, No. 4.

Lachenbruch, P. A. (1975). Discriminant Analysis, Hafner, NY.

Ohlson, J. A. (1980). "Financial Ratios and the Probabilistic Prediction of Bankruptcy," Journal of Accounting Research 18, 109-131. Shumway, T. (2001). "Forecasting Bankruptcy More Accurately: A Simple Hazard Model," Journal of Business 74, 101124. 
Slatter, S. P. (1984). Corporate Recovery: Successful Turnaround Strategies and Their Implementation, Richard Clay Pte Ltd., Singapore, Penguin Books.

Tudorel, A. (2000). 'Analysis of Structural Changes through Regression Models,' Romanian Statistical Review V. 49, Nr. 7, P. 23-34.

Tudorel, A. (2009). 'Applications in Econometrics,' Economic Publishing.

Tudorel, A., Iacob, A., Iluzia, A., Stancu, S. \& Tusa, E. (2008). 'Introduction in Econometrics Using Eviews,' Economic Publishing.

Verwijmeren, P. \& Derwall, J. (2010). "Employee Well-Being, Firm Leverage, and Bankruptcy Risk," Journal of Banking \& Finance 34, 956-964.

Vintilă, G. \& Toroapă, M. G. (2011). Building a Scoring Model for Bankruptcy Risk Prediction on Multiple Discriminant Analysis, the International Conference "Present Issues of Global Economy"- 8th Edition, April 16th17 th, Annals of the "Ovidius" University, Economic Sciences Series Volume XI, Issue 1 /2011, 2283-2287.

Voineagu, V., Titan, E. \& Serban, R. (2006). 'Theory and Econometric Practice,' Meteor Press.

Zmijewski, M. E. (1984). "Methodological Issues Related to the Estimation of Financial Distress Prediction Models," Journal of Accounting Research 22 (Suppl.), 59-82. 